\title{
Erratum to: Safe Use of Wastewater in Agriculture
}

\author{
Hiroshan Hettiarachchi and Reza Ardakanian
}

\section{Erratum to:}

\section{H. Hettiarachchi and R. Ardakanian (eds.),}

Safe Use of Wastewater in Agriculture, https://doi.org/10.1007/978-3-319-74268-7

The original version of the book was inadvertently published without the credit line in the cover photo, which has been now included. The erratum book has been updated with the change. 